\title{
Birth Control
}

\author{
Siniša Franjić* \\ Faculty of Law, International University of Brcko District, Brcko, Bosnia and Herzegovina, Herzegovina
}

Submission: August 27, 2018; Published: September 19, 2018

*Corresponding author: Siniša Franjić, Faculty of Law, International University of Brcko District, Brcko, Bosnia and Herzegovina, Herzegovina, Email: sinisa.franjic@gmail.com

\begin{abstract}
Birth control is the name for the implementation of one or more actions aimed at deliberately preventing or reducing the chances of pregnancy or childbirth. In practice, there are several methods which have different characteristics. An important role in the implementation of birth control is the attitude of religious communities which people belong to, for which can be said to be unequal.
\end{abstract}

Keywords: Birth; Control; Family; Abortion

Abbreviations: FP: Interest in family planning; SRH: sexual and reproductive health; CTOPA: Choice on Termination of Pregnancy Act

\section{Introduction}

It has been a little less than 100 years since the words birth control first appeared in print, but birth control, as a social practice, is as old as human history [1]. Since the beginning of civilization, women were expected to produce children from marriage to menopause, in a constant battle to birth more children than died in utero, in infancy, or of childhood disease. Yet women in every era and culture, acting alone or with their husbands or lovers, sought ways to delay childbearing or reduce the odds of pregnancy. They did so in spite of cultural and religious prohibitions or societal pressures to increase the size of the tribe. Couples attempted family limitation for reasons that included their own health and sanity and the well-being of their existing children, economic benefits of a smaller family, to reduce the population in times of disease or famine, and because of particular circumstances of time and place.

A woman's body undergoes significant changes in pregnancy, with the developing fetus making increasing demands [2]. Preparation for pregnancy should begin before conception, as fetal development begins from the third week after the last menstrual period. Damaging effects (e.g. exposure to drugs) may occur before the woman is even aware she is pregnant. Being as fit and healthy as possible before conception maximizes chances of a healthy pregnancy, but not all poor obstetric outcomes can be avoided. Pre-pregnancy counselling by a specialist team is recommended where specific risks and diseases are identified.

Besides contraception, two other deliberate methods of family limitation, abortion and infanticide, have also been practiced throughout history, sometimes rarely and at other times with far greater frequency than contraception. However, neither act, occurring after fertilization and birth respectively, is considered a form of birth control in the context of this narrative. While infanticide is usually viewed as a most extreme form of population control and is universally condemned in the modern era, perceptions about abortion have changed repeatedly over time. Abortion has been conflated with contraception in the past, and strong debate continues as to whether it should be considered an acceptable and legal form of reproductive control. It is worth noting that the birth control movement of the early 20th century, which evolved into a reproductive rights movement that vowed to make and keep abortion legal, set out initially to end the practice of abortion, which was then illegal.

\section{Reproductive Freedom}

The principle of reproductive freedom stipulates that people have the right to make their own reproductive choices and that the state has an obligation to foster conditions under which this can occur [3]. For some, this principle is morally objectionable because it grants women the right to make decisions concerning the termination of unwanted pregnancies. In their view, whatever rights pregnant women may or may not have, they do not override the fetus' right to life or prenatal care. The problem with this view is that it rests on the highly contested belief that the fetus has a right to life and a right to be born of sound mind and body."

Others endorse the principle of reproductive freedom but advocate for what they believe to be legitimate restrictions on this principle as it applies to pregnant women. They maintain that a woman has a limited right to terminate her pregnancy but that once she has chosen to continue her pregnancy, she incurs obligations to protect and promote the health and well-being of her fetus and the state incurs obligations to limit or preclude 
actions that would irreversibly harm the future person. These obligations to the fetus are grounded in the belief that the fetus has a right not to be damaged and a right not to be deliberately or negligently harmed.

\section{Family Planning}

Interest in family planning (FP) has grown globally in recent years due to the Family Planning 2020 (FP2020) Initiative [4]. It is a global partnership, an outcome of the London Summit on Family Planning held in 2012, that supports the rights of women and girls to decide, freely and for themselves, whether, when, and how many children they want to have. At the 2012 London Summit, 69 countries pledged to bring modern contraception within reach of an additional 120 million women and girls by the year 2020. Achieving the FP2020 goal is seen as a critical milestone to ensuring universal access to sexual and reproductive health (SRH) services and rights by 2030, as laid out in the UN's Sustainable Development Goals 3 (ensure healthy lives and promote well-being for all at all ages) and 5 (achieving gender equality and the empowerment of women and girls).

Globally, demographic and health surveys in 52 countries between 2005 and 2014 reveal the most common reasons that married women cite for not using contraception despite wanting to avoid a pregnancy. Twenty-six per cent of these women cite concerns about contraceptive side effects and health risks; $24 \%$ say that they have sex infrequently or not at all; $23 \%$ say that they or others close to them oppose contraception; and $20 \%$ report that they are breastfeeding and/or haven't resumed menstruation after giving birth. Women with unmet need for contraception rarely say that they are unaware of contraception, that they do not have access to a source of supply, or that it costs too much. Compared with earlier studies on women's reasons for not using contraception, a larger proportion of women now cite side effects and infrequent sex as reasons for nonuse. Contraceptive services should place priority on improving the information and counselling they provide and the range of methods they offer. All sexually active women, whether married or not, need information about their risk of becoming pregnant and about the choices of methods that could meet their needs.

Family size preferences have only been explored by sample surveys in recent years, as improved fertility regulation has made family size more directly a matter of personal choice [5]. Two rather different aims have inspired the exploration of this area:a desire to monitor changes in ideals and intentions which may influence achieved family size, and a hope that expected family size might be used in forecasting fertility. The main achievement so far has been to identify some crude trends in orientations to family size and spacing. The relevance of such findings can only be assessed through a further programme of longitudinal research.

Unwanted pregnancy and contraceptive effectiveness are of interest both as indicators of the extent to which family size preferences may be achieved and also as a means of evaluating the impact of contraceptive services. The use of proxy measures such as abortion and illegitimacy was seen to be problematic, but there are also limitations in a sample survey approach.

The job of family planning remains unfinished [6]. Despite great progress over the last several decades, more than 120 million women worldwide want to prevent pregnancy, but they and their partners are not using contraception. Reasons for unmet need are many: Services and supplies are not yet available everywhere or choices are limited. Fear of social disapproval or partner's opposition pose formidable barriers. Worries of side effects and health concerns hold some people back; others lack knowledge about contraceptive options and their use. These people need help now.

Millions more are using family planning to avoid pregnancy but fail, for a variety of reasons. They may not have received clear instructions on how to use the method properly, could not get a method better suited to them, were not properly prepared for side effects, or supplies ran out. These people need better help now.

The influence of family structure on fertility behavior is a classic question in social demography [7]. Theoretically, there are expectations that extended family structure provides support for early childbearing and consequently a high level of fertility. Shared economic costs of children and child care, as well as an emphasis on family continuity and encouragement of early marriage, and early childbearing from parents, are often cited as some of the main reasons why extended family systems may induce high fertility.

To test empirically for the linkage between family structure and fertility behavior, a diverse range of dependent variables have been used by researchers. Among them are various fertility measures, including actual fertility, desired family size, and birth spacing, as well as other processes of family formation, such as age at marriage, and age at first birth.

\section{Responsibilitiy in Family}

Most people interested in family sociology and family law seem to agree that families are changing [8]. Whether we look simply at the demographic data or at the more nuanced research that demonstrates changes in the nature, manifestations and experiences of personal commitment and responsibility, we all have to admit that something is happening. Some of us may be pleased by the changes and some of us disconcerted or even frightened by them, but research shows that 'family life' for many of us is lived outside the heteronuclear married norm and includes forms of group marriage, serial monogamy, unmarried different or same sex cohabitation, non co-resident intimate partnerships or living apart together, step-parenthood and/ or lone parenthood, not to mention other household communities including the non-conjugal homesharers with whom the Law Commission had so much trouble in 2002 (Law Commission 2002) and disregarded in 2006 (Law Commission 2006). Sociologists 
tell us that these relationships are important to people; they provide stability, intimacy, care, and companionship. They are central to people's core values. Family sociologists further tell us that friendship practices are changing so that there may be a blurring of lines between friends and family. In all of these new family practices, connectedness operates in more various ways than simply through sexual intimacy or blood.

\section{Marriage}

Marriage traditionally has meant the union of a man and a woman as husband and wife [9]. The term has been used in a variety of ways over the years. There are ceremonial marriages (also known as traditional marriages), common law marriages, covenant marriages, putative marriages, and same-sex marriages, to name just a few.

Marriage has evolved and changed over the centuries. It is an institution that has legal, societal, and religious implications. Many contend that its most basic function is to provide for a stable environment to have and raise children, thus perpetuating the human species. Whatever its origins, it is certainly an institution that is intertwined into many areas of the law. For example, it is a basis for determining property rights in probate and intestacy proceedings and provides tax advantages in some cases to married couples.

Marriage, to those involved in one, can mean a legal tie, a symbol of commitment, a privileged sexual affiliation, a relationship of hierarchy and subordination, a means of selffulfilment, a social construct, a cultural phenomenon, a religious mandate, an economic relationship, the preferred unit for reproduction, a way to ensure against poverty and dependence on the state, a way out of the birth family, the realization of a romantic ideal, a natural or divine connection, a commitment to traditional notions of morality, a desired status that communicates one's sexual desirability to the world, or a purely contractual relationship in which each term is based on bargaining [10].

\section{Abortion}

In what circumstances, if any, is it legitimate for a woman to terminate an unwanted pregnancy [11]? Instinctive responses to this question will lie somewhere upon a spectrum which has 'never' at one end, and 'whenever she likes' at the other, with most people falling somewhere in between, believing that abortion is sometimes, but not always justifiable. Towards the restrictive end of the spectrum, it might be argued that abortion is legitimate where the woman's life is in danger, or when she is pregnant as a result of rape. At the more permissive end, it might be contended that abortion should be available upon request, at least during the first few months of pregnancy.

The majority of women who come to an abortion center or an hospital have made up their minds about wanting to have the procedure. Most facilities that provide abortion services include counseling as part of the woman's visit [12]. The counseling session typically includes a discussion of the woman's decision to have an abortion and her comfort with that decision. During this process the counselor will listen and ask questions to make sure that this is the woman's decision and that her decision is free from coercion or pressure from others.

Most women do not experience negative emotions following having an abortion. Many of the women who do experience some fluctuations in mood following an abortion only do so for a few days after the procedure. For those women who are experiencing negative emotions for more than a few days following an abortion, they may choose to speak to a therapist or call the center where they had the abortion procedure. Women can receive therapist referrals from the centers where they had the abortion procedure. Therapists might want to contact local abortion providers and make themselves known as a source for referrals.

Courts and advocates typically conflate illegal abortion with the risks of unsafe abortion as the problem that formal law cures [13]. In Portugal, the Constitutional Court's decision reflects women's rights advocates' argument that if the law did not allow time-limited abortion, women would inevitably seek dangerous, illegal terminations. According to the Court, this was "the empirical reality of social life" and "incontrovertible data gathered from past experience."

For many women in many countries, however, this is not the reality. In countries like South Africa and Colombia, a well-known informal sector for abortion provision persisted well after legal reform. In South Africa, the illegal abortion rate remains high despite the CTOPA (Choice on Termination of Pregnancy Act), which guarantees abortion on request through twelve weeks of pregnancy. Studies in Colombia demonstrate that self- induced abortion via over-the-counter drugs persists even for women who could have obtained legal abortions. Given that formal rules may not govern practice as expected or as designed, recognizing and understanding the complex informal norms and rules that govern abortion makes the practice of abortion law intelligible. We might consider, for example, countries with state tolerance of widespread quasi-or extralegal abortion practice.

\section{Birth}

It has been women's unique and irreplaceable function in the species to give birth to new human beings, at least until now, and perhaps for just a little while longer [14]. Such power as women have had in the past derived primarily from that potentiality, whether or not they actually performed that function. The primary imperative was to express rather than to control fertility, and to realize the capacity for nurturance through childbearing. Yet women have always sought, and found, ways to control their fertility. At the same time, for most women, during most of recorded history, the inability to bear a child, or children, when desired was considered a personal and social problem ranging from moderate to severe. In many parts of the world, even today, bearing children-sometimes bearing only male children-is still 
a woman's only justification for existence. In all societies, most women still feel that children and families represent their major life work, whatever else they may do or wish to do. Birth for them is mainly a means to that end, hopefully, but not certainly, a safe one.

\section{Birth Control}

All modern societies struggle to define the proper relationship between the state and the private lives of the citizenry, and sexual behavior is often the central arena of this conflict [15]. The state becomes involved in the regulation of sexuality though legislation. through the provision (or lack of provision) of sexually related services such as contraception, and through ideological messages. Yet such attempts at regulating sexuality are often resisted. Some argue that the state simply has no business intervening in this most private sphere of human activity. Others, while acknowledging the legitimacy of state involvement. disagree strongly about the character and extent of this involvement. Sexual conservatives typically call for state power to be used to restore "traditional morality" (through, for example, antipornography campaigns and statefunded agencies that counsel "chastity"); sexual liberals, on the other hand, frequently argue that the state has not gone far enough in assuring the "sexual rights" of all its citizens (and call for birth control and abortion to be made available to all who need them. irrespective of their financial situation).

Birth control, as it was called by such leaders of contemporary Western sexual enlightenment as Margaret Sanger (American social reformer), offered a new sovereignty over unborn life, first to women and then to the medical profession and the state [16]. For half a century the birth control movement publicly maintained the moral distinction between contraception and abortion, extolling the former while condemning the latter as barbaric and unnecessary. The rhetoric called for a pedagogy that would instruct patients (that is, women) and doctors in the responsible control of conception. Until the early 1970s, the rubric family planning concealed a change in attitudes that had taken place among supporters of birth control who also endorsed a less inhibited sexuality. With the rise of the contemporary women's movement, the right to obtain an abortion became a prerequisite to the liberation of women. The assertion that control over one's body must include the right to choose abortion was quickly countered by the assertion that the taking of life is never permissible.

As Alan Guttmacher (distinguished American obstetriciangynecologist) noted in the 1960s, some form of birth control has been used by societies around the globe for thousands of years [17]. But the explosion in the number of artificial birth control alternatives really belongs to the twentieth century. When the only options were pessaries and condoms, the debate over birth control was more unidimensional. As the industrial revolution and its technological innovations led to IUDs (intrauterine device) and hormonal-based contraceptives, the debate assumed new dimensions. And now, in the twentyfirst century, the availability of new streams of communication has added one more layer of debate. No discussion of the issues and controversies surrounding birth control can be complete without fully understanding the type of birth control method and the context in which it is used.

Despite the prevalence of birth control use in American society, the type and extent of public support for contraceptives remains very controversial. The root of all debate over birth control rests in the various presuppositions of moral order and natural law. At this level, there is little room for compromise and little hope for widespread public consensus. For the sake of policymakers who need to find some broad agreement, most debates avoid questions of universal principles and focus instead on specific questions of access, health, and propriety. At the level of public debate, the wide spectrum of moral assumptions can be more easily categorized into more manageable policy questions.

According Zorea, types of Birth Control is Natural Birth Control Methods, Early Artificial Birth Control Methods, Intrauterine Devices, Hormonal-Based Contraceptives, Long-Acting Hormone-Based Contraceptives, "Emergency" Contraceptives, Recent Innovations and Marketing and Sterilization.

\section{Conclusion}

Birth control is a common name for many different procedures whose purpose is to prevent the child's conceive, but also to prevent the birth of an already conceived fetus. The most commonly used method for this purpose is called a contraceptive method. On the other hand, the term abortion refers to a procedure that represents the physical removal of the fetus and means its death. Birth control is a controversial topic around the world that is conditioned by social, religious and customary reasons. Attitudes to these issues differ widely across the globe and still today there is a fierce debates about these issues. In any case, these are issues about which will be much discussed in the future.

\section{References}

1. Engelman PC (2011) A History of the Birth Control Movement in America. J Clin Invest 121(10): 1-2.

2. Collins S, Arulkumaran S, Hayes K, Jackson S, Impey L, et al. (2013) Oxford Handbook of Obstetrics and Gynaecology. In: ( $3^{\text {rd }}$ edn), Oxford University Press, Oxford, UK, p. 30.

3. Baylis F, Rodgers S, Young D (2008) Ethical dilemmas in the care of pregnant women: rethinking, maternal-fetal conflicts. In: Singer PA, Viens AM (Eds.), The Cambridge Textbook of Bioethics, Cambridge University Press, Cambridge, UK, pp. 97-103.

4. Satia J, Chaukan K (2018) Improving Quality of Care in Family Planning-A Research and Advocacy Agenda for India. Springer Nature Singapore Pte Ltd, Singapore, pp. 1-3.

5. Selman PF (1988) Family Planning. Chapman and Hall Ltd, London, UK, p. 97.

6. Look VPFA (2011) In Foreword of Family Planning - A Global Handbook for Providers. World Health Organization, Geneva, Switzerland, Johns Hopkins Bloomberg School of Public Health, Baltimore, USA. 
7. Chen F (2006) The impact of family structure on fertility. In: Lee DL Chang CF, McKibben ShL, Walther CS (Eds.), Fertility, Family Planning and Population Control in China. Routledge, Taylor \& Francis Group, Abingdon, UK, p. 49.

8. Diduck A (2008) Family Law and Family Responsibility. In: Bridgeman J, Keating H, Lind C (Eds.), Responsibility, Law and the Family. Ashgate Publishing Limited, Aldershot, UK, p. 251.

9. Kent GW (2009) Family Law for Paralegals. The McGraw-Hill Companies Inc, New York, USA, p. 37.

10. Herring J (2009) Family Law. In: (4 th $^{\text {th }}$ edn), Pearson Education Limited, Harlow, UK, p. 39.

11. Jackson E (2016) Medical Law-Text, Cases, and Materials. In: ( $4^{\text {th }}$ edn), Oxford University Press, Oxford, UK, p. 699.

12. Needle RB, Walker LEA (2008) Abortion Counseling-A Clinician's Guide to Psychology, Legislation, Politics, and Competency. Springer Publishing Company, LLC, New York, USA, p. 174.
13. Rebouché R (2014) A Functionalist Approach to Comparative Abortion Law. In: Cook RJ, Erdman JN, Dickens BM (Eds.), Abortion Law in Transnational Perspective -Cases and Controversies. University of Pennsylvania Press, Philadelphia, USA, p. 110.

14. Swenson N (1980) Childbirth Overview. In: Holmes HB, Hoskins BB, Gross M (Eds.), Birth Control and Controlling Birth- Women-Centered Perspectives. The Humana Press Inc, Clifton, USA, p. 143.

15. Joffe C (1986) The Regulation of Sexuality-Experiences of Family Planning Workers. Temple University Press, Philadelphia, USA, p. 208.

16. Imber JB (2017) Abortion and the Private Practice of Medicine. In: (1 $1^{\text {st }}$ edn)Taylor \& Francis Group, Routledge, New York, USA, pp. 204.

17. Zorea AW (2012) Birth Control. Greenwood, ABC-CLIO, LLC, Santa Barbara, USA, pp. 23-24.

Your next submission with Juniper Publishers will reach you the below assets

- Quality Editorial service

- Swift Peer Review

- Reprints availability

- E-prints Service

- Manuscript Podcast for convenient understanding

- Global attainment for your research

- Manuscript accessibility in different formats ( Pdf, E-pub, Full Text, Audio)

- Unceasing customer service

Track the below URL for one-step submission https://juniperpublishers.com/online-submission.php 